\title{
“We can't just be a county that supports inebriants": Voices of the noncannabis agricultural community
}

Interviews with noncannabis producers in Northern California revealed a variety of concerns about legal cannabis production, from access to land and crop shifts to outsider investments.

by James C. LaChance

$\mathrm{T}$ raveling over the ridges and through the fertile valleys of Humboldt, Mendocino and Sonoma counties, one encounters a variety of farms, ranches, wineries and farm stands - and now a proliferation of cannabis industry billboards. Touting cannabis appellations and the ease of acquiring cannabis goods and services, their message is loud and clear: legal recreational cannabis has arrived. As the cannabis sector has come fully into public view, so too has its interaction with noncannabis agriculture.

In Humboldt, Mendocino and Sonoma counties, as in other California counties, cannabis regulations over the expansion of recreational cultivation are still being refined. The uncertainty about how they will impact local economies, environments and communities is also affecting the noncannabis agricultural community. The changes farmers and ranchers will undoubtedly face are situated within broader questions about farmland transitions in the United States.

Clockwise from left, billboards announcing the new legal status of recreational cannabis use have sprung up in Northern California; a soil amendment advertisement outside a farm supply store targets cannabis growers; a fertilizer aisle at a Northern California farm supply store caters to cannabis growers.

\section{Finance, land access, crop shifts}

Across the United States, farmland is increasingly subject to financial investment and speculation. Research suggests that financial investment in the food system
Online: https://doi.org/10.3733/ ca.2019a0016

\section{Abstract}

Legalized recreational cannabis poses uncertainty and challenges for the noncannabis agricultural and ranching community in Northern California, including what it might mean in terms of the price of farmland and ranchland and the effects on the regional culture of diverse crop production. In-depth interviews in Humboldt, Mendocino and Sonoma counties with noncannabis farmers, ranchers and key individuals closely tied to the community revealed insight and an overarching concern about the future for noncannabis producers in those counties. The research was conducted in the summer and fall of 2017, when the state and counties were ramping up development and implementation of recreational cannabis cultivation policies. Interviewees expressed concern about land prices, potential crop shifts, and outside investment in the cannabis sector, and recognized the parallels and emerging alliances between wine and cannabis producers. They also identified opportunities for diversifying their production and for improving the environmental impacts of cannabis production.
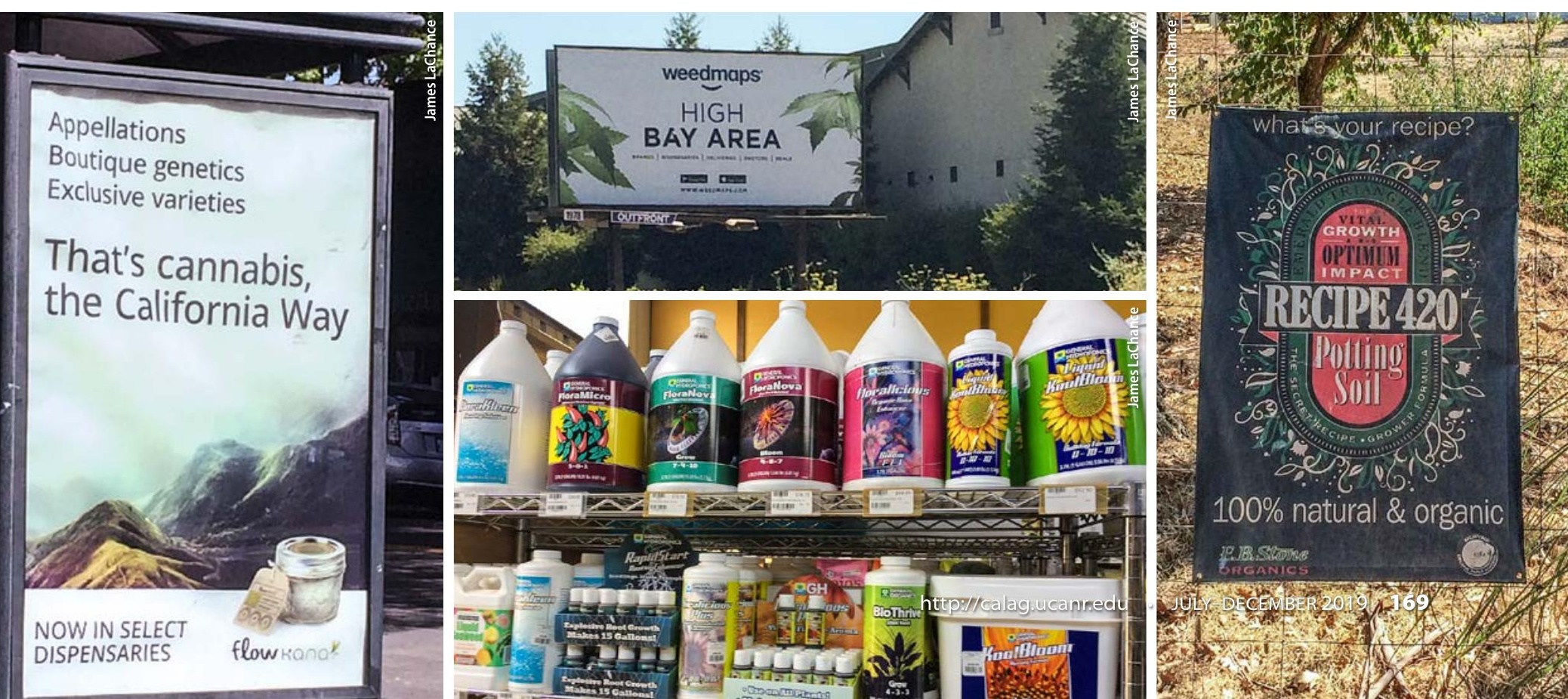
has already had considerable impacts on food production in some regions, including investments in farmland, food processing, agricultural inputs and more (Burch and Lawrence 2009). Questions of scale and implications of ownership have long been a focus of agricultural research, as these factors clearly shape farming communities and can lead to negative socioeconomic and community outcomes (Goldschmidt 1978; Lobao and Stofferahn 2008).

In some rural areas of the United States, outside financial investors have caused land values to rise and increased farmer tenancy while decreasing farmer ownership. U.S. Department of Agriculture (USDA) statistical data confirm this trend in California; many counties have seen an increasing amount of both rented land and nonoperator landlords - common indicators of financial investment in farmland (Nickerson et al. 2012). Other research has reported on these trends, particularly how financial actors - from hedge funds to university endowments - have acquired farmland across the United States (Fairbairn 2014; Kesmodel and Newman 2015).

The expansion of recreational cannabis production in Northern California intersects with this trend. Articles have highlighted entrepreneurs developing industrial-scale cannabis farms in the Central Coast (Fuller 2017), rapid consolidation of cannabis markets across North America (Kelloway 2018) and large corporate alcohol interests - Constellation, Molson Coors and others - investing billions of dollars in the cannabis industry (Maloney 2018; Miller 2018).

Outside investments in land can amplify the challenges food producers face. Already in much of California there is a history of significant land use change and crop regime shifts (Walker 2004). Particularly in Northern California, food producers have experienced the effects - for example, Sonoma County apple growers have been impacted by the arrival of grapes and a related increase in farmland prices. More broadly, conventional growers in California have been impacted by organic production increasing the price of farmland (Guthman 2014). But grapes and organics are not directly analogous to cannabis. Until recently, cannabis had never legally been grown for recreational use on California land zoned for agriculture; it was instead part of the counterculture (Meisel 2017).

\section{Environmental concerns, new revenues}

The uncertainty being experienced in the noncannabis agricultural community also extends to environmental concerns. Reports have been published about rodenticide poisoning and excessive irrigation use in cannabis (Bauer et al. 2015; Gabriel et al. 2012); furthermore, recent research described how despite the overall small footprint of cannabis production on the landscape, it can have significant negative impacts, including to landscape fragmentation and important ecosystem processes (Wang et al. 2017).

The shift to legal production of recreational cannabis brings with it a chance to create environmental standards for the industry. Regulations might begin to curtail negative environmental impacts as producers transition into the legal framework. Furthermore, now that production has been legalized, some noncannabis growers might choose to diversify their agricultural operations to bring an influx of new revenue. A recent article asked whether Ukiah, in Mendocino County, could become the "Napa of pot" (Swindell 2018).

\section{Collecting the perspectives of the noncannabis sector}

As cannabis development continues and counties negotiate policy and regulatory decisions, it is vital that evidence of impacts and opportunities be collected and that community members, including noncannabis farmers and ranchers, maintain a voice in the negotiations. My research project was undertaken to better understand and articulate the farming and ranching communities' perspectives and needs postProposition 64 in Northern California. It was born out of conversations with UC Cooperative Extension (UCCE) specialists who noticed an increased frequency with which the noncannabis farming and ranching communities discussed interactions with the cannabis sector surrounding the passing of Proposition 64.

Of specific interest was how these interactions were being talked about at food policy council meetings in Northern California. At the outset, it was clear that these conversations covered a spectrum of opinions ranging from apprehension to optimism. It was also clear that while the division between the cannabis and noncannabis communities was not always completely transparent - in some cases, noncannabis farmers may at times have grown cannabis on the side - this framing was useful for beginning to understand key themes related to what could be a divisive topic.

The project took place in the summer and fall of 2017, and it was completed before Jan. 1, 2018, when legal recreational cannabis cultivation began. Research was approved by the UC Berkeley Committee for Protection of Human Subjects Institutional Review Board, Protocol ID 2017-05-9973. Humboldt, Mendocino and Sonoma counties were selected because they approximate a gradient of food production versus cannabis development, include a diversity of food and fiber production, and adopted different regulatory frameworks for recreational cannabis. Livestock is the largest agricultural enterprise by gross production value in Humboldt County, and wine grapes are the main enterprise in Mendocino and Sonoma counties (table 1).

TABLE 1. Crop value data in Humboldt, Mendocino and Sonoma counties, 2016 (the most recent year data is available from all three counties): the top three crops by gross production value, the number of million-dollar crops in the county and the total gross value of the agricultural commodities from each county. Sources: County of Humboldt 2017; County of Mendocino 2018; Sonoma County ND.

\begin{tabular}{|l|r|}
\hline Humboldt County & \\
\hline Top 3 crops & \\
\hline Livestock products & $\$ 99,695,000$ \\
\hline Livestock & $\$ 90,488,000$ \\
\hline Timber production & $\$ 70,395,000$ \\
\hline No. of million-dollar crops & 7 \\
\hline Total gross for all county crops & $\$ 326,076,000$ \\
\hline
\end{tabular}

\begin{tabular}{|c|c|}
\hline \multicolumn{2}{|l|}{ Sonoma County } \\
\hline \multicolumn{2}{|l|}{ Top 3 crops } \\
\hline Wine grapes & $\$ 586,517,700$ \\
\hline Milk & $\$ 146,475,400$ \\
\hline Misc. poultry & $\$ 40,823,200$ \\
\hline No. of million-dollar crops & 14 \\
\hline Total gross for all county crops & $\$ 898,125,200$ \\
\hline
\end{tabular}


Average farm size in Humboldt and Mendocino counties is similar, around 630 acres; in Sonoma County, there are many more farms and the average size is 165 acres (fig. 1). In terms of acreage, all three counties have most land farmed as pasture (fig. 2).

Information about land use and top-ranked noncannabis crops (by value) produced in each of the three counties is provided in figures 1 and 2 and table 1. These figures and tables are from 2016 county-level crop reports that track agricultural commodities, which do not include cannabis. At the time of this research similar data on legal recreational cannabis was not available, and collecting information such as historical production trends and the identity of cannabis growers was not the focus of this research. To date, USDA census of agriculture data does not exist, as cannabis remains federally illegal.

I conducted preliminary interviews with UCCE and related agricultural professionals to develop research questions before interviewing 24 key informants across the three counties. The interviewees were selected to include a wide range of people familiar with cannabis and agricultural trends in the region but especially those who were closely connected to the policymaking and regulatory process: they included state and county officials involved in agriculture, cannabis regulation, planning, building and zoning; realtors; food policy council members; members of prominent farming and

\section{Humboldt County}

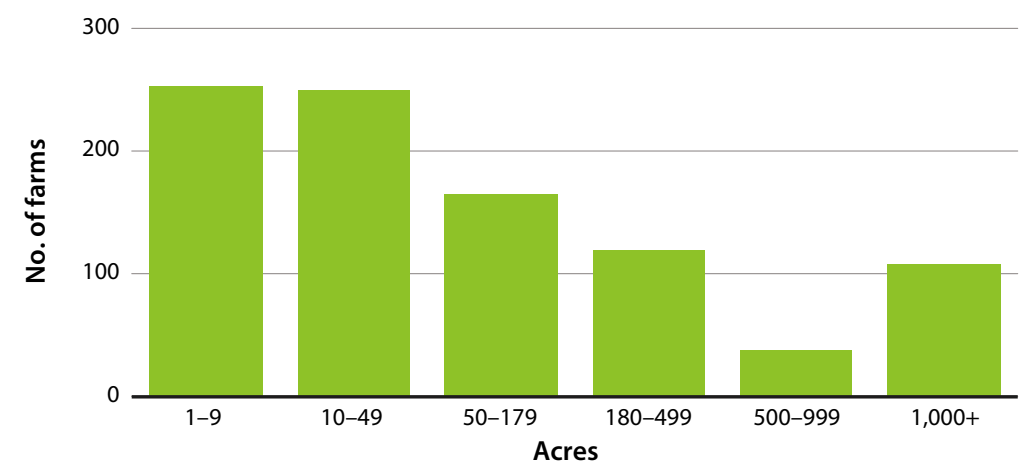

Mendocino County

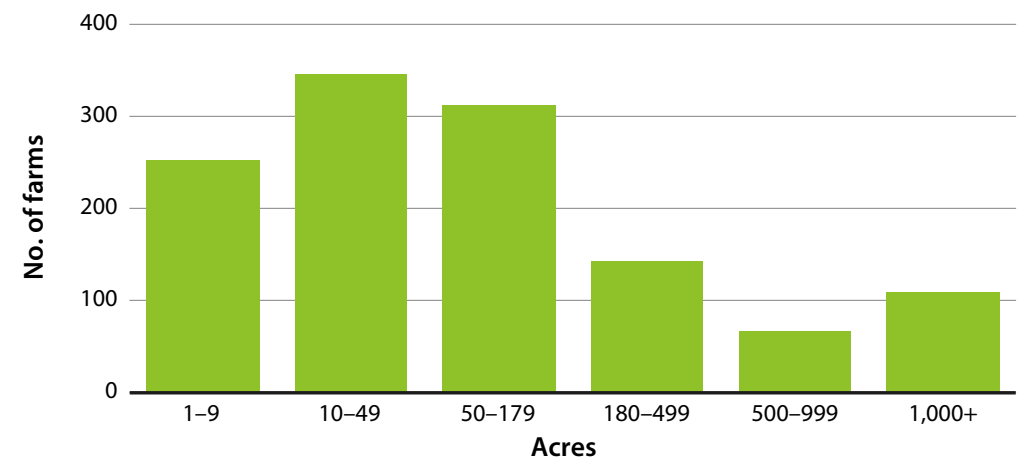

\section{Sonoma County}

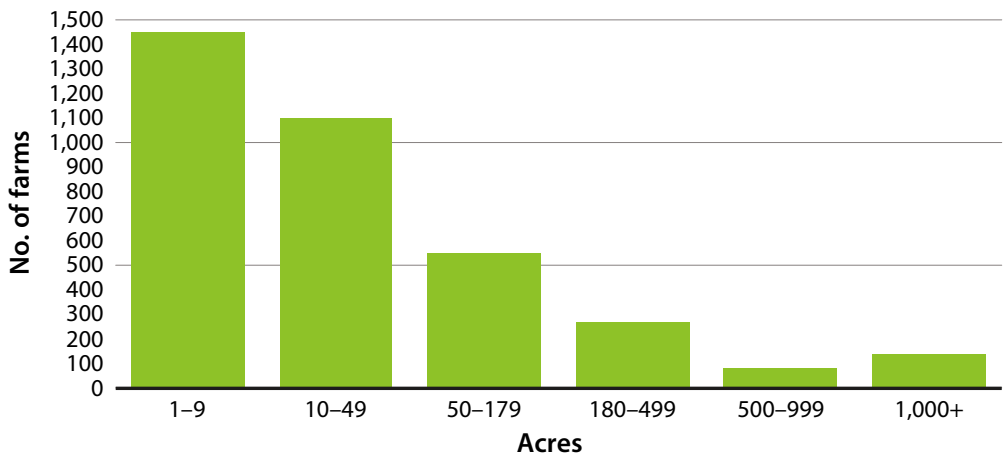

FIG. 1. Number of farms by size in each county, 2012. Humboldt County: 930 farms, average size 638 acres; Mendocino County: 1,220 farms, average size 631 acres; Sonoma County: 3,579 farms, average size 165 acres. Source: USDA NASS 2012.

\section{Humboldt County}

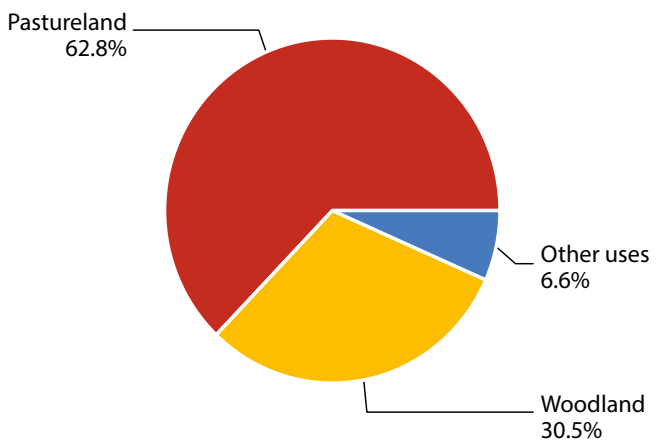

\section{Mendocino County}

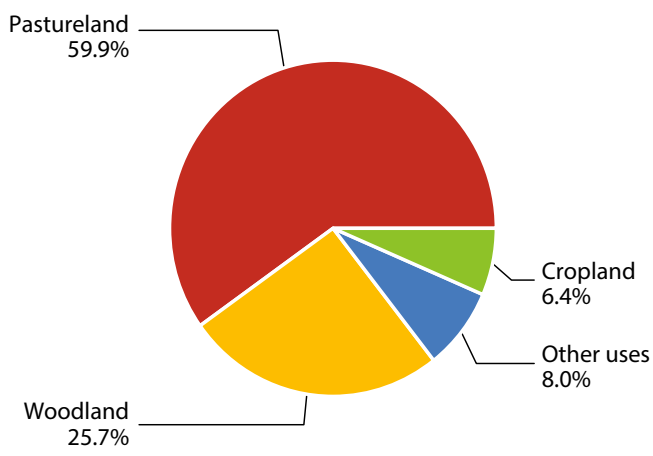

\section{Sonoma County}

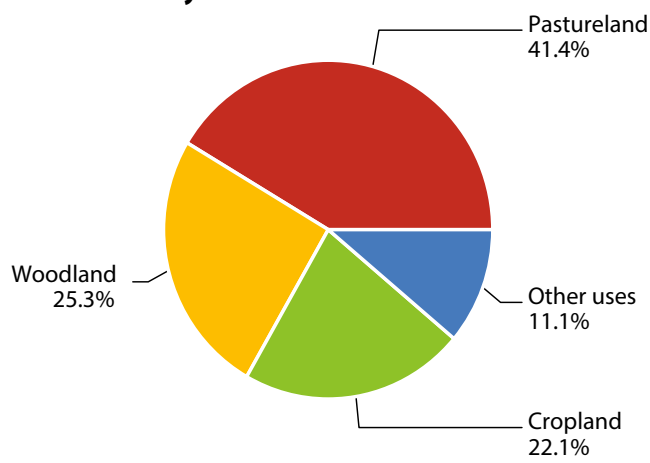

FIG. 2. Land use in each county, 2012. Source: USDA NASS 2012 
TABLE 2. Guiding questions for interviews

\section{Introduction}

Can you tell me a bit about how long you've lived or worked in Sonoma/Mendocino/Humboldt County and about your connection to the agricultural and ranching community?

\section{Character of the county's agriculture and ranching community}

Have you heard of any positive or negative interactions between noncannabis agriculture and cannabis?

What are your thoughts on how the legalization of cannabis might impact food production in the county?

Do you think that recreational cannabis might impact noncannabis agriculture's ability to access any particular resources, such as land, water, or labor?

How do you think the legalization of recreational cannabis might impact the operation of farms and ranches in the future?

What do you think will be the biggest impact for the operation of Sonoma/Mendocino/ Humboldt's noncannabis farms and ranches from the legalization of recreational cannabis?

What are your opinions about the legalization of cannabis as it relates to farming?

\section{Access to land}

In the time that you have lived there, has who owns the land changed in Sonoma/Mendocino/ Humboldt?

a. What do you think is responsible for the biggest change in ownership?

b. Where does most of the buying and selling of land happen?

Have you noticed any changes to the price of land recently?

a. Why do you think that is?

b. Do you have a sense of who is buying the land?

I've heard that in some counties agricultural land is being purchased for cannabis production. Have you heard of anything like that happening in your county?

Have you heard from farmers about how it has been securing land to rent or own lately?

a. Have you heard of a change in how much is owned vs. rented?

b. Do most producers have landlords in Sonoma/Mendocino/Humboldt?

Do you know who is generally growing or intends to grow recreational cannabis?

Do you know who is making these investments in cannabis?

a. Or who, in terms of farmland companies, is managing or purchasing land in the county?

b. Any specific examples?

TABLE 3. A range of interviewee perspectives describing perceived and potential impacts of increased cannabis industry development

\begin{tabular}{|c|c|c|}
\hline Negative & Neutral & Positive \\
\hline Land price volatility & $\begin{array}{l}\text { Shifts in culture of each } \\
\text { county's agriculture and } \\
\text { ranching communities }\end{array}$ & Diversification of crops \\
\hline $\begin{array}{l}\text { General uncertainty of impacts to } \\
\text { community }\end{array}$ & $\begin{array}{l}\text { Changing crop regimes } \\
\text { and "new frontiers" }\end{array}$ & $\begin{array}{l}\text { Opportunity for cannabis } \\
\text { to indirectly subsidize } \\
\text { food agriculture }\end{array}$ \\
\hline $\begin{array}{l}\text { Potential spillover of new } \\
\text { regulations into noncannabis sector }\end{array}$ & Land use changes & $\begin{array}{l}\text { Opportunity for } \\
\text { environmental } \\
\text { improvement }\end{array}$ \\
\hline $\begin{array}{l}\text { Negative crop and neighbor } \\
\text { interactions (e.g., smell, wine taint, } \\
\text { livestock damage, crime, etc.) }\end{array}$ & Zoning changes & $\begin{array}{l}\text { Opportunity for } \\
\text { economic development }\end{array}$ \\
\hline $\begin{array}{l}\text { Challenges to land access, } \\
\text { particularly for new and beginning } \\
\text { farmers and those who lease land }\end{array}$ & $\begin{array}{l}\text { General shift in culture of } \\
\text { broader community }\end{array}$ & $\begin{array}{l}\text { Increased opportunities } \\
\text { for farmers and ranchers } \\
\text { to lease land to cannabis } \\
\text { producers }\end{array}$ \\
\hline $\begin{array}{l}\text { Attraction of mega-businesses (e.g., } \\
\text { "Philip Morris,"“'Walmart of weed") } \\
\text { that do not align with more common } \\
\text { cottage industry production }\end{array}$ & & $\begin{array}{l}\text { Tax revenues for county } \\
\text { and state }\end{array}$ \\
\hline $\begin{array}{l}\text { Labor impacts (increased } \\
\text { competition for labor) }\end{array}$ & & Improved public safety \\
\hline
\end{tabular}

ranching organizations and agriculture and ranchingrelated nonprofit organizations; and other key agricultural community members.

Interviews were open ended, semistructured and generally lasted 1 to 2 hours. I asked questions about access to land and other resources, trends in investment, change to land use and natural resource use, and the character of the county's agriculture and ranching (table 2). The interview recordings were transcribed and analyzed for key themes using NVivo qualitative data analysis software (QSR International, Melbourne, Australia); then interviews were coded and representative quotations selected as evidence. A range of perspectives from these findings are summarized in table 3 . Four main themes emerged.

\section{Losing access to farmland, resources}

Much of the agricultural community was concerned about the burgeoning cannabis industry impacting access to land and other natural resources. Across the three counties, interviewees often identified this concern in terms of an increased presence of corporate and financial interests from outside the county being attracted to the region to grow cannabis, and those interests' ability to compete with and displace members of the agricultural community. These "outsider" interests were frequently described as hedge fund managers, large corporations, cartels and black market interests with foreign ties, and wealthy individuals. As one interviewee described:

I had a guy that I talked to who's sort of almost a hedge fund manager type portfolio investor who's like, "I have \$4.5 million to spend and I can't find anywhere to spend it. I literally cannot find property." Or that he could've purchased for cannabis operation that would meet all of the county's or the city's criteria. So there are people who are hovering and I think that Sonoma County is seen as a really desirable area.

Those "hovering" prospective producers or landowners contrast with the cottage industry producers who have historically been the most common type of cannabis producer in the region.

Many interviewees mentioned they had heard rumors of Philip Morris and other corporate tobacco interests moving into the region to transition part of their business to cannabis. One interviewee said,

I've heard from [a county employee] that Philip Morris is poised for purchasing land in Humboldt soon. And where he's received that information, I don't know, but that's what he shared over dinner recently. 
In addition to Philip Morris, interviewees feared an influx of "mega-businesses," "the Walmart of weed" and nonspecific foreign interests:

I've heard of companies like in China and stuff like buying up big pieces of land, so I feel like some of the people that are coming here from foreign countries are actually coming to buy the land and do larger grow operations ... that's definitely a possibility.

While the majority of interviewees who discussed outside investment were concerned about its impact on food production, not all shared that concern. Particularly in Humboldt, a subset of interviewees felt that food production would not be impacted by legalization of recreational cannabis; they largely attributed their lack of concern to the significant role cannabis already plays in the county:

\section{All of the real fertile, flat ground is still farmers' market people because they're family owned and stuff. In Humboldt County, it's not going to affect our food production that much. We don't have that much food production.}

Some interviewees highlighted how the regulations on the type of parcels that can be used to grow cannabis made finding suitable cannabis land difficult, implying that it should not put pressure on noncannabis producers:

This is the most highly regulated crop in the history of mankind.... So the properties that actually fit all the different restrictions [placed] on cannabis, they're few and far between ... It's kind of like a needle in a haystack. Yeah. So those properties that can meet all the restrictions we've placed on cannabis cultivation are up in value. But not all ag land is seeing an increase in value because if it doesn't fit the parameters [placed] around cannabis cultivation you can't use it for cannabis cultivation...

\section{Navigating volatile land prices, lease transitions}

A second key theme was interviewees' concern about how cannabis development might impact farmland prices and lease arrangements. Some interviewees emphasized that cannabis was not the only factor at play with the high land prices in Northern California:

It's been impossible to secure or rent ag land in Sonoma County for a long time, honestly. I mean this is a conversation that I've been having since I started farming 10 years ago. We're really lucky we farm on family land ... but I've done a lot of work with California FarmLink and some of the
Many interviewees mentioned they had heard rumors of Philip Morris and other corporate tobacco interests moving into the region to transition part of their business to cannabis.

\begin{abstract}
organizations that have tried to connect farmers to land. And so it's a problem that we've identified and haven't really found an adequate solution to, quite frankly, for food farming and diverse ag. Before, the conversation was more about "food farming and diverse ag, how do we carve out space for that?" But now there's a conversation for "How do we carve out space for cannabis in light of sort of vineyards everywhere and then disallowing [cannabis operations] from being on rural residential and ag residential?"
\end{abstract}

There were many reasons interviewees were concerned about recreational cannabis legalization inflating land prices further, but being outcompeted for all types of land was of particular import:

People who can come in and drop \$10,000-plus an acre, cash, for landlocked parcels with no water typically aren't going to be your everyday farmer. [It's] people who want to be left alone and, typically, they're going to be growing cannabis... So if you were the base property owner and you see the gold rush that's happening, [then] you put property on the market and within 10 minutes it's sold. And it's been pretty quick.

Or as another put it, per-acre revenue for cannabis has been exceeding the revenue for noncannabis crops for some time:

The only difference between home-grown tomatoes and home-grown cannabis is that if you've got a little raised bed the size of this table, you can grow enough tomatoes for a couple of weeks of salads ... you could probably grow $\$ 100$ worth of tomatoes. But cannabis, with just this amount of space, you're saying - even if it's just for your own consumption or your friend's consumption or whatever - you are saying the equivalent of thousands of dollars.

Related to the increase in the value of land, there has been an increase in the cost of rents for leased ground. Many interviewees described lost leases or changing lease arrangements and pointed to the higher prices that cannabis growers pay as the main culprit:

And that's the other thing ... that they've lost their leases that they've held for 25 or 30 years because this is the time where the base property owners are getting older, or the next generation doesn't want 
to keep it ... And so they've seen those grapes get ripped out, and they put cannabis greenhouses and infrastructure and all that.

Lease challenges were of particular concern to interviewees in Sonoma and Mendocino counties, with one interviewee summing up how the small-scale and beginning farmers they work with face unique challenges:

A good majority of our farmers lease... the questions that our [small and beginning] farmers are facing ... is, "How do I secure five acres? How do I afford five acres, period? If I can lease, how can I keep it?" The challenge is not just finding it, but then finding a secure, stable land because it's just coming and going all the time.

This prospect of small and beginning farmers competing with cannabis operations was often a key concern among interviewees;

Overall, interviewees in each county most often expressed concern about the impacts of cannabis on their county's top crops. For Humboldt, this included livestock and timber land; for Mendocino and Sonoma, it was timber, grape and dairy production. whereas, concerns about vineyards competing with cannabis operations were less prevalent and usually focused on competition over labor at harvesttime.

Overall, interviewees in each county most often expressed concern about the impacts of cannabis on their county's top crops (table 1). For Humboldt, this included livestock and timber land; for Mendocino and Sonoma, it was timber, grape and dairy production. Interviewees also described significant concerns about the impact of cannabis on low(rural) and moderate-density residentially zoned land.

\section{Fearing culture change}

One of the most prominent themes across all three counties was the fear of major changes to the culture of the region. Interviewees in Humboldt and Mendocino counties, which both have a well-known cannabis history, were concerned that their county's name recognition could bring change to the culture and scale of cannabis cultivation as well as to general agriculture. One interviewee appraised the issue optimistically:

Realistically, I'm hoping that when it becomes legal and the feds approve it, then the [Central] Valley will take over and create the Bud and Coors versions. And then, [Mendocino County will be] the mom and pop places [and] do the boutique stuff. It'll be like what we do for wine, we'd do for pot.

Others emphasized the complexity of the situation and described how cannabis is just one change of many that agriculture has faced, although complications were mentioned around the social dynamic:
I mean, agriculture shifts. That's nothing new to us. There will be something that replaces wine grapes someday. Historically here, it was hops, and prunes, and pears, now it's grapes. We've seen the transitions here in the [Ukiah] valley... We've seen transitions from sheep ground and more intensive agriculture with wine grapes over in Anderson Valley, and that's the nature of the beast ... And so, hell, for all we know, we could see, like I said, pears coming out and cannabis going in. We don't know. I mean there's kind of a social dynamic of that where people would have to accept growing cannabis and I think that's probably not going to happen anytime soon necessarily from our more traditional folks.

Across the three counties, the majority of interviewees agreed with the idea that shifts in cash crops were "nothing new," and some identified cannabis as the next frontier:

We're on that sort of edge of transition, just like my father-in-law was when he planted his orchards 40 years ago. My whole family property used to be prunes and pears. He learned that he could make more money on one acre of vineyard than he could on the entire property of hay, and prunes, and pears, which is what it was growing. So, of course, you try to keep a family property in the family.

Others echoed this sentiment yet hoped that the county could continue to have diverse food production:

We can't just be - many people have said this we can't just be a county that supports inebriants [laughter]. Beer, wine, cider, cannabis. Hard alcohol. And that is a huge part of our economy now, and what is attracting tourists and investors ... Where is the food going to come from?

Another interviewee said,

I did the calculation ... every single resident in Sonoma County could stay intoxicated - totally inebriated 24 hours a day, year-round - and we'd still have lots leftover.

Relatedly, a small number of interviewees in Humboldt and Mendocino lamented that their local farm supply stores did not always carry what they needed for raising crops or livestock but instead catered to the cannabis industry.

\section{Hoping for economic and environmental benefits}

Interviewees expressed hope that new revenue streams and development opportunities might exist for the agricultural community and the county, and that 
environmental benefits would ensue from transitioning producers into the legal recreational cannabis system.

Regarding economic impacts, there was a balance of positive and negative opinions, the magnitude of which was often borne out in a discussion of labor costs:

For the vineyards, [the biggest impact] is going to be labor. Access to labor. Well, [livestock] too. I mean, if you can go in and - I can't remember what the numbers are, but you can make a lot more money picking buds than you can picking grapes or milking cows ... and it's cash money.

Several interviewees suggested that cannabis could be an opportunity for diversification, either by cultivation of cannabis or by leasing land to a cannabis grower. As one interviewee suggested, however, it is a thorny and uncertain opportunity:

We've got a lot of small producers that are growing produce, and whether they see this as an opportunity to supplement income, there's - and again, it just gets back to there's so much that's still out there about it still being federally illegal, and especially if you're connected to the vineyard industry and the wine industry, you got to be really careful about that. If you're using or incorporating THC products into your business model then you're jeopardizing your ability to market wine, that's what I'm hearing.

Interviewees mentioned other potential negative economic impacts from the cannabis industry, including: the smell of cannabis cultivation pervading rural residential neighborhoods; guard dogs from illegal grows harassing and injuring livestock; and the complaint of "wine taint," or the smell of cannabis cultivation being found unintentionally, and to a negative outcome, in wine. In Mendocino, several interviewees mentioned a new cannabis regulation potentially affecting noncannabis producers and increasing their costs for certain types of farm infrastructure projects.

Many interviewees expressed hope that regulations for the legal sector would bring environmental benefits:

And, really, what they're trying to do is they want everybody to be in compliance. They're not trying to make everything shut down. There's a big issue here with the environmental degradation from the cannabis farming, and I would say I feel like having lived here when I was young and then being here now, there is a dramatic difference. Again ... it seems like it's just a dramatically different cannabis industry here now than it was 30 years ago. And there is a lot more people coming in from out of the area and foreign countries to work here, and there's a lot more of those illegal grows that are inside and are using a lot of resources as well as dumping a lot of toxic material into local habitats, and that's very different than what I remember it

being when I was younger.

\section{The uncertain future}

The research findings suggest that a range of interactions have been evolving between cannabis growers and noncannabis farmers and ranchers in Humboldt, Mendocino and Sonoma counties. The noncannabis sector has faced many new challenges and uncertainties during the process in which recreational cannabis transitioned to legality. Accordingly, interviewees continued to express mixed feelings about how these actions would continue to unfold.

The comparison of cannabis growing to vineyards, while imperfect, was nonetheless generally useful for interviewees to begin to picture what types of landscape and community changes could come about, particularly in Mendocino and Sonoma counties. Lessons may be gleaned from the precedent of transitions to wine grape vineyards, and may be used to inform policy and community approaches to both harmonizing and mitigating impacts of cannabis on noncannabis communities. For example, when considering Sonoma's transition to wine grapes and the correlating increase in farmland prices, it would be useful to identify what strategies non-wine grape producers relied on to keep farming non-grape crops,

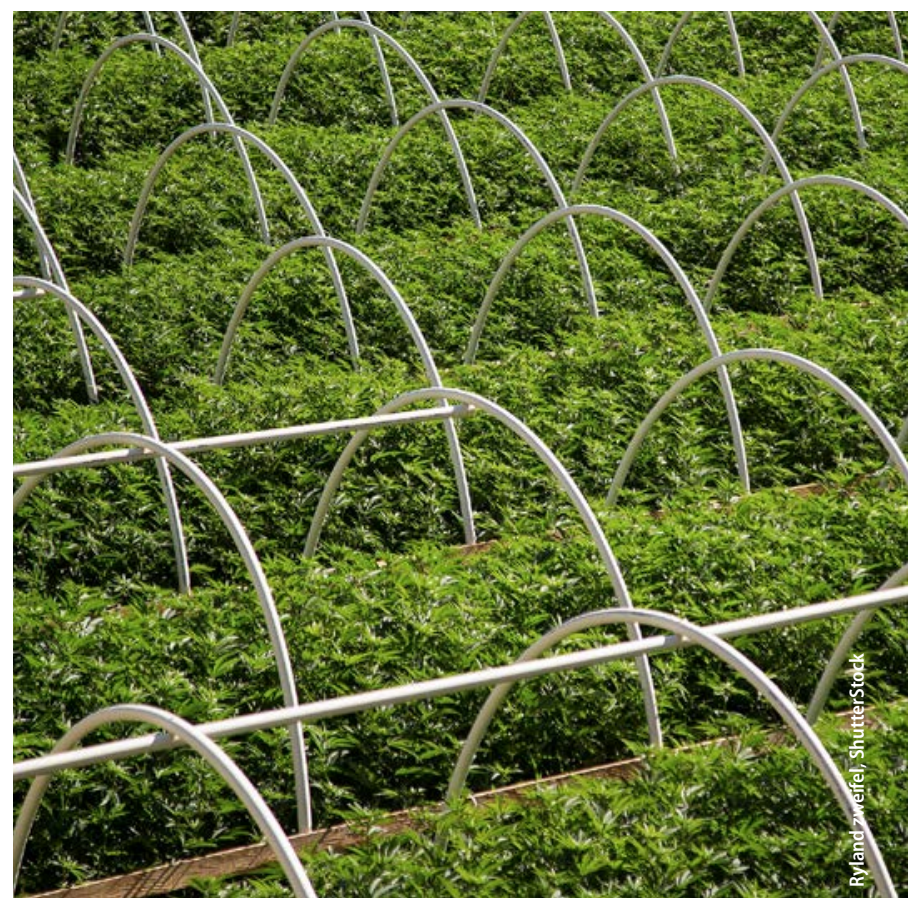
and whether certain producers found ways to subsidize non-grape crops (e.g., renting part of their land to grape growers in order to subsidize their own maintenance of growing a non-grape crop).

The experience of transitioning pear and apple orchards to wine grapes - the current paradigm of cash crop transition in this region - stands to be a useful parallel for policymakers when considering the range of possible changes that may occur within the landscape, community and economy as the potential result of further transitioning farmland to growing cannabis. Broader changes that resulted from the precedent of grapes, whether positive or negative, may stand to be a sobering example to consider for policymakers hoping primarily for economic gains to be had from expanded cannabis cultivation.

As several interviewees mentioned, cannabis does not fall under Right to Farm laws, or laws that protect
Lessons may be gleaned from the precedent of transitions to wine grape vineyards, and may be used to inform policy and community approaches to both harmonizing and mitigating impacts of cannabis on noncannabis communities. 
the right to conduct standard agricultural practices in a community. This highlights a key shortcoming of the cannabis and wine grapes analogy, as the expansion of the legal cannabis industry is not afforded the same rights as the expansion of wine grapes in an agricultural community. Nonetheless, in some areas legalization of recreational cannabis may bring with it an overhauling of the current landscape of food production, just as wine grapes did. The divide that some interviewees noted between wine producers and other food producers perhaps mirrors the divide between cannabis producers and noncannabis producers. Interestingly, wine producers - and, as previously mentioned, the alcohol industry in general - have already made various commercial connections with cannabis producers, with collaborations ranging from a "wine and weed" conference in Sonoma in summer 2017 to cannabis-infused beer and wine.

Newly developed regulations surrounding cannabis cultivation will have great significance for food producers in these counties. As they are refined, it is important that policymakers continue to involve the agricultural community and intentionally incorporate their perspectives. This should be done through outreach with individuals, organizations and food policy councils to ensure that new regulations for cannabis are not unintentionally spilling over into agriculture (as some interviewees suggested) or otherwise compromising the diversity of producers in these counties.

The interviews reported here establish a baseline knowledge of how legalized recreational cannabis intersects with agricultural communities. Future research could focus on investigating land sale and ownership data to see what land types are targeted by which type of investors in each county, and to then begin to determine what types of outcomes might be associated with these different types of investors. Meanwhile, the land situation during this transition period is fluid. In Humboldt County, after the end of the study reported here, a recent town hall meeting highlighted the economic crisis facing the community with the decline of the price of cannabis. Community members reported that property values had dropped and that large, and not small, cannabis businesses had generally been receiving the bulk of new permits (Futcher 2018).

In addition to more research, a renewed effort might be made to prioritize support for farm succession planning and explore creative approaches to transitioning key pieces of farmland to the next generation of farmers who identify with the noncannabis community. Such an initiative could bolster efforts to maintain diverse local food systems in Humboldt, Mendocino and Sonoma counties. CA

\footnotetext{
J.C. LaChance is a Ph.D. Candidate, Department of Environmental Science, Policy, and Management, UC Berkeley.

This project was sponsored by the UC Graduate Student in Cooperative Extension Fellowship Program. The author would like to thank Van Butsic, Yana Valachovic, Stephanie Larson, Clare Gupta, Jenny Sowerwine and Kathryn De Master for their guidance. Thanks are also especially due to the interviewees for taking the time to share their valuable insight.
}

\section{References}

Bauer S, Olson J, Cockrill A, et al. 2015. Impacts of surface water diversions for marijuana cultivation on aquatic habitat in four northwestern California watersheds. PLOS ONE 10(3):e0120016.

Burch D, Lawrence G. 2009. Towards a third food regime: Behind the transformation. Agric Human Values 26(4):267-79. County of Humboldt. 2017. 2016 Crop Report. https:// humboldtgov.org/DocumentCenter/Niew/61579/2016CROP-REPORT?bidld= County of Mendocino. 2018 2016 Crop Report. www. mendocinocounty.org/home/ showdocument?id=23680

Fairbairn M. 2014. 'Like gold with yield': Evolving intersections between farmland and finance. J Peasant Stud 41(5):777-95.
Fuller T. 2017. Marijuana goes industrial in California. New York Times, Apr. 15. www nytimes.com/2017/04/15/us/ california-marijuana-industryagriculture.html?smprod=nytcore iphone\&smid=nytcore-iphoneshare

Futcher J. 2018. Cannabis crisis in Humboldt County. Anderson Valley Advertiser, Aug. 29. http:// theava.com/archives/86956

Gabriel MW, Woods LW, Poppenga R, et al. 2012. Anticoagulant rodenticides on our public and community lands: spatia distribution of exposure and poisoning of a rare forest carnivore. PLOS ONE 7(7):e40163.

Goldschmidt W. 1978: As You Sow: Three Studies in the Social Consequences of Agribusiness. Montclair, New Jersey: Allenheld, Osmun.

Guthman J. 2014. Agrarian Dreams: The Paradox of Organic Farming in California. Berkeley: UC Press.
Lobao L, Stofferahn CW. 2008 The community effects of industrialized farming: Social science research and challenges to corporate farming laws. Agric Human Values 25(2):219-40.

Kelloway C. 2018. Rapid consolidation in Canada's cannabis market raises fears among small growers - Both north and south of the border. Open Markets Institute Food and Power blog. www. foodandpower.net/2018/05/24/ rapid-consolidation-in-canadascannabis-market-raises-fearsamong-small-growers-bothnorth-and-south-of-the-border/ Kesmodel D, Newman J. 2015. Farmland investments take root. Wall Street Journal, Aug. 4. www.wsj.com/articles/ farmland-investments-takeroot-1438661041
Maloney J. 2018. Corona brewer bets $\$ 4$ billion on cannabis startup. Wall Street Journal, Aug. 15. www.wsj. com/articles/constellationbrands-expands-investmentin-cannabis-company-canopy growth-1534332997

Meisel J. 2017. Hidden in plain sight: Cannabis cultivation in the emerald triangle. Calif Geographer 56:3-26. http://hdl. handle.net/10211.3/193762

Miller B. 2018. Molson Coors makes cannabis-infused beverage deal in Canada. Denver Business Journal, Aug. 1. www cnbc.com/2018/08/01/molsoncoors-makes-cannabis-infusedbeverage-deal-in-canada.htm Nickerson C, Morehart M, Kuethe K, et al. 2012. Trends in US Farmland Values and Ownership. USDA ERS Economic Information Bulletin 92. www. ers.usda.gov/webdocs/publications/44656/16748_eib92_2 $\mathrm{pdf} ? \mathrm{v}=41055$
Sonoma County. ND. Crop Report 2016. https://sonomacounty.ca.gov/WorkArea/DownloadAsset.aspx?id=2147544202

Swindell B. 2018. The Napa of pot? Some say Ukiah is perfectly positioned as its business culture opens up. Press Democrat, Aug. 13. www. northbaybusinessjournal. com/northbay/mendocinocounty/8631182-181/ mendocino-retail-cannabiseconomic-growth

[USDA NASS] US Department of Agriculture National Agricultural Statistics Service. 2012. County Profiles. www.nass.usda.gov/ Publications/AgCensus/2012/ Online_Resources/County_Profiles/California/index.php

Walker R. 2004. The Conquest of Bread: 150 Years of California Agribusiness. New York: New Press.

Wang IJ, Brenner JC, Butsic V. 2017. Cannabis, an emerg ing agricultural crop, leads to deforestation and fragmentation. Front Ecol Environ 15(9):495-501. 